\title{
Strategy for the Preservation of the Puppet Art Tradition in the Modern Era: A Case Study of Wayang Museum in Jakarta
}

\author{
Priyanto* \\ Tourism Laboratory Vocational Education Program, Universitas Indonesia \\ *Email: Priyanto15@ui.ac.id
}

\begin{abstract}
A decreasing interest in traditional art forms is one of the influences of globalization in Indonesia. The traditional art of wayang was recognized by United Nations Educational, Scientific, and Cultural Organization (UNESCO) in 2003 as a Masterpiece of the Oral and Intangible Heritage of Humanity and it represents a cultural inheritance that is vulnerable to disuse because of a lack of contemporary patronage. Of course, for the art of the wayang tradition to survive, its records must be preserved and the artform must be further developed. The Wayang Museum in Jakarta is an institution that contributes to the preservation of traditional wayang art through activities such as the curation of exhibitions, the organization of performances, the holding of lectures, and so on. This study aims to review the activities of the Wayang Museum in Jakarta and the investigation was undertaken in stages: first, data were collected through observation; next, they were described, and finally, they were conceptually interpreted via the activities of the museum. The results of this study indicate that the Wayang Museum in Jakarta has implemented its objectives in a satisfactory manner. Further, the study recommends the use of digital media for the repackaging of traditional wayang art in a contemporary manner so that it can be preserved and fostered for future generations.
\end{abstract}

Keywords: traditional art, puppet, Wayang Museum

\section{Introduction}

Globalization has exerted a significant impact on the existence of traditional Indonesian art, namely the wayang. Some studies suggest that globalization influences the abandonment of traditional art forms such as the wayang kulit, wayang potehi, kasidah art, gambang art, reog art, and ludruk performing arts. Declining interest in the traditional arts, especially among the younger generation, eventually causes a dilution of a nation's culture (Ghani, 2018; Lis, 2014; Nalan, 2016).

wayang kulit The current neglect of the wayang kulit culture may be seen as a by-product of globalizationwayang kulit. Indonesian youth should exhibit more interest in their own culture and should help in the preservation of unique indegenous artforms instead of trying to imitate the cultural artifacts of other nations. Such a dilution has already happened once in Indonesia, and youngsters should be wary of letting it happen again. Respecting other cultures should not imply the adoption of the artforms of other nations to the detriment of indegenous cultural legacies such as the wayang kulit.

Given the declining interest in traditional arts, museums have been institutionally pivotal to the preservation of indegenous cultural artifacts. According to the International Council of Museums (ICOM), a museum serves the functions of collecting and securing a people's cultural heritage. It documents, stores, conserves, and preserves the historical legacies of a culture. Further, it conducts scientific research and takes on the task of the equitable dissemination of public knowledge. It creates a general recognition and appreciation of the arts, introduces inter-cultural, natural, and indegenous phenomena, and acts as a mirror of the growth of human civilization. Ultimately, museums serve to cultivate the sense of caution to God Almighty through their collective resources and their programs of activity (O'Connell, 2016).

A museum that has contributed to the preservation of wayang traditional art is the Wayang Museum in Jakarta, located at Jalan Pintu Besar Utara No. 27, West Jakarta. Initially, the Wayang Museum building in Jakarta was named De Oude Hollandche Kerk (Dutch Old Church) and was first built in 1640. It was renovated in 1732 and renamed De Nieuwe Hollandche Kerk (Dutch New Church) but in 1808, the building was destroyed by an earthquake. Nearly a century later, in 1912, another building was constructed on the ruins of the church, and a few decades after Indonesia's independence, the building was inaugurated as the Wayang Museum on 
August 13, 1975. Although the construction is relatively new, some parts of the old and new churches are still visible in the building (Banowosari, Rahma, Rizky, \& Fuady, 2013).

The Wayang Museum in Jakarta has a rich collection of puppets and dolls and exhibits various types and forms of puppets from all over Indonesia. These puppets are made of varied materials such as wood, leather, etc. Additionally, the museum also houses and exhibits puppets from overseas countries such as China and Cambodia. As per the latest records, the Jakarta Wayang Museum owns a collection of more than 5,147 puppets including the wayang kulit, wayang golek, wayang kardus, wayang grass, wayang janur, mask, wayang beber, and gamelan. Generally, the dolls exhibited at the Jakarta Wayang Museum are European dolls, although some figurines are of non-European origin and exemplify the crafts of Thailand, Suriname, China, Vietnam, India, and Colombia (Banowosari et al., 2013).

The Jakarta Wayang Museum took on the important task of preserving and developing Indonesian wayang art, wayang kulit especially after November 7 2003, when the UNESCO, declared wayang to be a Masterpiece of the Oral and Intangible Heritage of Humanity (Grahita \& Komma, 2014). Since then, the Wayang (or puppet) Museum of Jakarta has played an important role in preserving the art of the wayang tradition through its activities and programs and by exhibiting its collection to people from all over the world.

Some studies have been conducted in relation to the preservation and development of the wayang artistic tradition. Banowosari et al. (2013) researched the Wayang Museum about the design concept of eyewear and the utilization of augmented reality at the museum. Research in new media has also focused on shadow puppet symbols and their interpretations. It has been argued that wayang kulit will continue to transfer traditional values to modern society through new media (Baharuddin \& Juhan, 2017).

The understanding of the essence and symbols of wayang kulit must be explored. This research endeavor specifically focuses on the shadow symbols of wayang kulit and their interpretations in new media. Wayang kulit

For instance, the wayang kulit culture may be preserved by utilizing a conceptual digital puppet model to help children learn math (Jasni \& Zulikha, 2016). Hence, the present paper proposes a conceptual model to illustrate how a digital wayang kulit can help students learn mathematics. The model posited in this paper developed a digital wayang kulit using the rapid application development method. The digital wayang kulit was given a persona and a name, e-Way cool, and it demonstrated how wayang kulit could be transformed into a tool for learning mathematics. However, to increase engagement in the digital wayang kulit and to make it more entertaining, an effective interaction design with three dimensions of interaction needed to be constructed (Jasni \& Zulikha, 2016).

Some studies relating to the preservation of the wayang art tradition have been discussed, but as is evident, the museum has not featured prominently in these studies. Therefore, this research initiative will attempt to explore the preservation of the wayang art tradition by the Wayang Museum in Jakarta.

\section{Literature Review}

\subsection{Traditional Art}

First, a specialist definition of art is required. Ki Hajar Dewantara, explains that art denotes all beautiful human actions that emanate from human emotions and that can move human feelings. Art can be categorized into traditional and modern forms. Some experts argue that traditional art is a manifestation of human inventiveness, taste, and intentions and that it serves varied functions in society. Traditional art may take the general form of ritual traditional art for religious ceremonies and customs, or it can be 'packaged' for the wider society and for tourists. Traditional art expert Soedarsono mentions the term, "packaging art." The art of packaging artificially promotes the characteristics of the original via a shortened, solidified, or an abridged version of the original that sets aside the sacred, magical, and symbolic value of the traditional art form and delivers variety at an economical price (Andri, 2016).

Traditional performance art cannot be separated from the show. In the performing arts, the occupations of individuals or groups are formed by the actions they undertake in a particular place and at a certain time. A performance can happen anywhere, anytime, or for varying durations. The performing arts involve four basic elements: time, space, the artist, and the relationship between the artist and the audience. Additionally, they may encompass other essential elements such as players, spectators, and messages. 


\subsection{Wayang Kulit}

Etymologically speaking, wayang means shadow (Javanese language: ayang-ayang), and this name perhaps stems from the fact that the performance artform of wayang is enjoyed through its shadow. Shadow puppets in traditional Indonesian art are generally made from animal leather processed into a sheet and sculpted according to the appearance of characters. Wayang is played by a dalang who acts as a narrator, and the stories that are depicted are usually taken from the two Hindu epics, the Mahabharata and the Ramayana. Wayang performances are usually accompanied by gamelan music and songs presented by the pesinden. Hence, the wayang, gamelan, and sinden have become combined into an integral whole. Shadow puppets are usually played behind a backlit white screen so that the audience can view the story through moving shadows. Thus, the audience must immediately be able to grasp the distinctive characteristics of every puppet character for the performance to be effective (Banowosari et al., 2013).

As has been mentioned above, on November 7, 2003 the UNESCO established the wayang performance as a marvelous cultural work, acknowledging the beauty of its narratives and its heritage value (Grahita \& Komma, 2014). Additionally, wayang can also be called a 'culture' as it amalgamates role art, sound art, musical art, the art of speech, literary art, painting, sculpture, and also symbolic art. Given its cultural significance and value, the declining interest in wayang is unfortunate, and Indonesian youth in particular must work hard to retain and to preserve the wayang culture.

Diverse types of puppets used in wayang. Some, as mentioned earlier, are made from animal skins. In other cases, such as the wayang golek that is typical of western Java, the puppets are made of wood. In addition, there are the types of wayang kulit gagrag Yogyakarta, which is so named because it has a distinctive shape, pattern of inlay, and sunggingan (coloring). However, this puppet show shares the other characteristics of the wayang: the 'play' or the presentation of plot and meaning, the chess or the narration and conversation, and the karawitan or the gendhing, embroidery, and other stage properties. Indonesia is also home to many more types of wayang such as the wayang kulit gagrag surakartan and the gagrag jawa timuran.

Wayang performances also feature both protagonists and antagonists in their cast of characters. Each puppet portrays a different character such as the five figures of the Pandawa brothers. It is thus imperative that the puppeteer is able to step into the shoes of all the characters. Therefore, the role of the puppeteer is not perfunctory; rather, the puppeteer is a master who is already familiar with the characters as well as with every detail of the puppets. In addition to the characters mentioned above, there are also the punakawan characters such as the semar, gareng, petruk, and bagong. These characters are not part of the main story and are inserted as comic relief for the audience.

In the current era of globalization, the wayang kulit is only used for the purpose of entertainment, which is in stark contrast to the use of the artform in ancient times, when shadow puppets were often used for da'wah media and for the spread of Islam, which was popularly disseminated by Sunan Kalijaga, a propagator of Islam in the island of Java. The shadow puppet show was intended to preserve Indonesian culture so that it did not become extinct. Wayang kulit educates society, so it would be incorrect to merely refer to this artform as a leather puppet show. While the performance itself does not act as a teacher, the array of moral and educational messages that are present in wayang performances serve to educate the audience about moral issues. Additionally, wayang kulit also serves as an alternative media for community educators because of its engaging nature of wayang kulit that educates people as it entertains them.

\subsection{Museum Concept}

The term 'museum' is derived from the Greek word museion, denoting the shrine (temple) dedicated to the muses, the nine goddesses who symbolize the various disciplines of the sciences and the arts. Over the years, the definition of a museum is has grown to encompass the following ideas: 1) The museum is a collection of rare items; 2) It is a compilation of scientific knowledge; 3). It accumulates scientific inventions. The formal definition of a museum was formulated by the member experts of the ICOM at the 11th ICOM General Assembly on 14 June 1974 in Copenhagen, Denmark.(MENA Report, 2018)

It is widely held that museums should be beneficial to society and that this objective can be accomplished if the museum performs its functions of preservation, research, and communication in an appropriate manner. Preservation includes both the physical and administrative maintenance of collections including the compilation, documentation, conservation, and restoration of knowledge and artifacts. In this conception, the acts of collection, documentation, conservation, and restoration of collections are not treated as interrelated functions but as aspects of a single function of collection management. (MENA Report, 2018)

The role of the museum has now expanded to research into the cultural heritage of people. The tasks of the museum curator now include the functions of being a researcher of collections. Such research pertaining to 
museum collections is necessary because the compilations in museums should be interpreted correctly and must be presented to visitors in a manner that offers them a profound experience. The interpretation and presentation of collated knowledge are important because they can stimulate visitors to go beyond the simple reading of labels attached to exhibited objects and to reflect on the meaning or the symbolism of exhibited artifacts. Hence, broadly speaking, museum collection research attempts to make the museum more significant for the community instead of merely a warehouse for rarities and curiosities (MENA Report, 2018).

Communication includes the dissemination of research results through activities such as exhibitions, educational programs, events, or publications. In this context, it becomes clear that a collection must first be interpreted before being exhibited so that the exhibited knowledge is informed by research. The presentation of an exhibition, on the other hand, takes into account its potential impact on visitors and is usually accomplished in a manner aimed at stimulating the imaginations of the visitors to a museum. The presentation of collections accompanied by the results of their interpretation conveys messages that can inspire visitors to look beyond the inanimate nature of collections or contemplate objects outside of their "normal" contexts (Quinn, 2018) (MENA Report, 2018).

\section{Methods}

The present investigation takes the form of a case study of the contemporary preservation strategy for the traditional artform of wayang by the Wayang Museum in Jakarta. The study uses a qualitative approach to accomplish its purpose. Qualitative research is an approach used to examine the condition of natural objects. In this methodology, the researchers play a key role, data analysis is inductive, and the results emphasize the construction of meaning.

This research project was conducted at the Wayang Museum in Jakarta, which is located at Jalan Pintu Besar Utara No. 27, West Jakarta. Primary data were obtained through observation of the museum's collection of puppets and through interviews with respondents such as the employees of the Wayang Museum in Jakarta. Secondary data for this research were obtained through a study of relevant literature in the form of documents, journals, articles, and other related materials.

\section{Discussion}

\subsection{Why Traditional Artforms are not so Interesting for the Public}

The data collected via observations and interviews in the Wayang Museum Jakarta evidence the public's declining interest in the wayang art tradition. Several reasons may be cited for this decline, including 1) The wide variety of entertainment media that are currently available such as television, the Internet, and cinema, which are easily accessible and are sometimes even free; 2) The lengthy puppet shows, which often last through the night and are perceived as being too time consuming and not trendy enough by members of the younger generation; 3) The puppet show is thought to be monotonous by the youth; 4) The use of the soft Javanese language called krama inggil, which is only understood by some people, makes puppet shows inaccessible to an extent; 5) The presumption of the younger generation that wayang kulit is ancient culture; and 6) The absence of facilities that can accommodate the development of novel and modernized shadow puppet creations.

In discussions and seminars organized by the Wayang Museum Jakarta, some wayang artists have conveyed their efforts to update the wayang tradition to accommodate the tastes of contemporary communities. These attempts include: 1) Introducing the wayang tradition to the younger generation from an early age to familiarize children with the artform and to inculcate in them a love for the wayang kulit culture so that it can be preserved for future generations; 2) Establishing a traditional wayang art studio so that the younger generation can learn and preserve the wayang kulit by utilizing the modernized media art facilities of the studio in creative ways and so that young people can develop their talents without any shame; 3) Organizing regular artistic performances of wayang kulit (e.g., weekly, and during the daytime instead of the night) instead of only during celebrations and festivities to make the artform more popular and desirable for the general public; and 4). Packaging traditional wayang puppet art in a modernized manner by adding another artform that can act as a distraction in the wayang performance, but that still does not change the power and appreciation of the puppet story itself. Four methods appear to stand out in this context: first, introducing the wayang art tradition to the youth from an early age can cause the youth to take an active interest in the wayang kulit culture, ensuring its preservation for future generations; second, establishing traditional wayang art studios can encourage the youth to engage with the artform and learn its ways; third, regularly organizing wayang kulit performances during the daytime instead of relegating them to nightlong shows on ceremonial occasions can lead to a greater awareness of the artform among people and can appeal to youngsters; and finally, modernizing wayang performances to include new 
media can go a long way to make the artform attractive for the youth by increasing audience engagement without diluting the essence of shows.

\subsection{Preservation Program for the Traditional Wayang Arts at the Puppet Museum in Jakarta}

The Wayang Museum in Jakarta is making concerted efforts to preserve the wayang traditions on the basis of numerous discussions and inputs from varied parties. Some of its programs include:

1. Exhibitions at the Wayang Museum in Jakarta

The Jakarta Wayang Museum regularly organizes exhibitions, both permanent and temporary. While permanent exhibitions are self-explanatory, temporary exhibitions include collections exhibited in the museum after some external events such as the Pameran Pameran Wayang, which was held only for a week.

The collection of the Wayang Museum currently amounts to about 5,147 pieces consisting of wayang kulit, wayang golek, gamelan, mask and so on However, only selected collections are exhibited in the Wayang Museum in Jakarta at any one time so that it does not look like a storage warehouse.(Banowosari et al., 2013)

Some notable aspects of the exhibitions curated by the Wayang Museum in Jakarta include 1). the museum selects the masterpiece collection to be exhibited, 2) the museum is able to package collections through exhibition activities to make them appear more interesting, 3) the museum arranges the exhibition spaces to look harmonious and artistic, and 4) the museum is able to explain the signification of the collection through the tables, panels, scouting and so on.

The implementation of a good exhibition program by the museum is expected to increase the footfall of visitors and to ameliorate public participation in the implementation of the pelaatatre wayang program.

2. Program Activities at Puppet Museum Jakarta

The Wayang Museum in Jakarta also regularly organizes performances and other activities that include: 1) the museum organizes a traditional wayang art performance encompassing golek puppet shows every second week, betawi puppet performances every third week, and purwa shadow performances every final week of every month; 2) the museum also showcases the creation of the wayang performance by periodically organizing shadow puppet shows such as wayang golek, wayang kulit, wayang rumput, and the like, along with karawitan demonstrations for the general public and students; 3) the museum hosts a wayang week; 4) the museum provides the services of guidance to visitors about the artform and undertakes other activities to introduce and preserve the wayang culture are conducted by the museum through the extension of wayang culture in the schools in the Jakarta capital city special region; 5) the museum conducts research on wayang traditional artforms; 6) the museum provides a puppet performance service and houses a fashion audio room that uses a three-dimensional home theater where visitors can see the short puppet performances; 7) the museum hosts coloring contests and puppet painting activities for young students; and 8) the museum arranges lectures, seminars, etc.

The packaging of performances is another consideration associated with performances at the Wayang Museum in Jakarta. Performances held at the Wayang Museum in Jakarta are generally not fully booked due to the declining interest in the art. It is the belief of the author of this paper that the usual four-hour-long shows and inaccessible language contribute to the fading interest in wayang kulit performances. Hence, it is suggested that the length of wayang kulit shows be reduced to one hour without diluting the essence of the performances. Likewise, the show should also be exhilarating and upload-worthy, and the use of language should be tailored to the needs of visitors (Varela, 2016).

3. Utilization of Digital Media for Preservation of Puppet Tradition Art

In the author's opinion, the wayang art preservation program at the Wayang Museum in Jakarta can be further improved through the utilization of digital media. The rapid advancement of digital technology can be used to package the art of the wayang kulit tradition for wider audiences. Digital media can eliminate the restrictions of time and space, allowing wayang shows to be enjoyed anywhere and at any time. For instance, live shows can be recorded and uploaded to the Internet via channels such as YouTube so that performances can be enjoyed over and over again at the convenience of viewers.

Additionally, digital technology can be utilized to transform traditional wayang kulit into digital wayang kulit. Traditionally, the puppets are made using the processes of carving or sculpting and coloring. This process can be accomplished digitally using image processing software, without discarding the existing controls in terms of the fundamental narratives and artform. Image processing software has a layering facility that stacks images and supports transparent images, making it possible to process and manipulate image objects to be combined with other images. Therefore, the term $e$-wayang denotes the process of making wayang using digital facilities (computerization) including the playing of the puppets on a computer screen. E-wayang can transform the entire traditional process from the beginning to the end into a digital environment, and can simultaneously allow the maintenance of the traditional control over the puppet-making. 


\section{Conclusions}

Declining interest in traditional artforms is one way for the manifestation of globalization in Indonesia. This fading appeal applies particularly to the puppet art tradition. The Wayang Museum in Jakarta is one of the institutions responsible for the preservation and development of traditional artforms and it has made the sincere effort to institute varied and projects to preserve the wayang tradition and make it more attractive to the public. One alternative that has not yet been optimized in the preservation of the traditional art of wayang is the use of digital technology, which would allow the art of the wayang tradition to be made popular and would enthuse the youth community.

\section{Acknowledgment}

Thanks to the Museum Wayang Jakarta and related parties who have provided much information and data related to this writing, Vocational Education Program, and Director of the Vocational Education Program the University of Indonesia.

\section{References}

Andri R.M., L. (2016). Seni Pertunjukan Tradisional di Persimpangan Zaman: Studi Kasus Kesenian Menak Koncer Sumowono Semarang. HUMANIKA, 23(2), 25-31.

Baharuddin, N., \& Juhan, M. S. (2017). Interpreting Wayang Kulit In New Media Practice: The Symbols Of Shadow. International Journal of Multidisciplinary Thought, CD-ROM. ISSN: 2156-6992::06(01):185-194.

Banowosari, L. Y., Rahmah, M., Rizky, G. A., \& Fuady, M. A. R. (2013). Design Concept of Augmented Reality Application with Glasses for Indonesia Wayang Museum. International Journal of Advances in Engineering \& Technology, 6(4), 1564.

Conservation, restoration \&; development of govt. museum alwar (new electric work) conservation, restoration \&; development of govt. museum alwar (new electric work) tender documents : T434097813]. (2018). MENA Report, Retrieved from https://search.proquest.com/docview/2031619113?accountid=17242

Ghani, D. A. (2018). Digital Puppetry: Comparative Visual Studies between Javanese \& Malaysian Art. International Journal of Applied Engineering Research, 13(6), 3579-3589.

Grahita, B., \& Komma, T. (2014). Identification of The Character Figures Visual Style in Wayang Beber of Pacitan Painting. International Journal of Asia Digital Art and Design, 18(3), 40-47.

Jasni, A., \& Zulikha, J. (2016). Digital Wayang kulit Model For Learning Mathamatics International Journal of Engineering and Applied Sciences ISSN: 1819-6608.

Lis, M. (2014). Contemporary wayang beber in central java. Asian Theatre Journal, 31(2), 505-523.

Nalan, A. S. (2016). Asep Sunandar Sunarya: Dalang of Wayang Golek Sunda (1955-2014). Asian Theatre Journal, 33(2), 264-269.

O'Connell, L. (2016). Toward a mutual understanding through culture: Art and politics in the past century. The Brown Journal of World Affairs, 23(1), 155.

Quinn, T. (2018). Un-disciplining the Art Museum: Museum Educators, Institutional Structures and Processes of Change (Order No. 10793250). Available from ProQuest Dissertations \& Theses Global. (2037203587).

Varela, M. E. (2016). Heirlooms of the Everyday: The Material Performances of Slamet Gundono. Theatre Research International, 41(1), 53-69. 